\title{
Analysis of the Strategy of Government's BIM under the International Comparative Perspective
}

\author{
Jianwen Cao ${ }^{1,}$, , Chufeng Chen ${ }^{2, b}$ \\ ${ }^{1}$ Central South University of Forestry and Technology, China \\ ${ }^{2}$ Central South University of Forestry and Technology, China \\ amrjwc@163.com, b1187600812@qq.com
}

\begin{abstract}
Keywords: BIM application; policy; BIM standard
Abstract. This paper summarizes the development policies of BIM technology by the United States, Britain, Singapore and Japan.From the policy-making organization, time, implementation to analyze governments' promotion of the development of BIM,And made recommendations for China's BIM development strategies for reference.
\end{abstract}

\section{Introduction}

BIM technology in many countries has formed a more mature standards and systems, the momentum of development in full swing.However, domestic BIM technology applications have not been widely used, and most are only used to assist the design or guide the construction ${ }^{[1]}$.The development of BIM technology in China is related to many factors. This paper summarizes the development policies of BIM technology by governments, and puts forward some suggestions for BIM development strategies.

\section{A Summary of BIM Policies at Home and Abroad}

A Summary of BIM Policies Abroad.In the United States, Britain, Singapore, Japan and other developed countries, BIM technology and its advanced concepts have been widely disseminated.In the government's strong impetus,BIM first in the public project has been demonstrated and applied, and gradually spread to private projects ${ }^{[2]}$. Table 1 is the specific compasion .

The US government combined with market demand to develop a more realistic plan of BIM, but most of the public projects and military projects.The NBIMS-US standard development is more perfect, One of the highlights of this standard is the integration of the parties involved in delivering project's lifecycle, according to a unified standard to sign all the contracts required for the project, a reasonable share of project risks, to some extent that is economic benefits.But the United States BIM standard only stay in the theoretical level, the actual operating experience is still shallow.

The British government has mandated the use of BIM technology as an important factor in the development of BIM.The UK government, with reference to the IFC standard and the COBie standard, creates a platform for producers and designers to communicate and share information $^{[3]}$. The industry for the British BIM standard evaluation is very high, not only has a strong maneuverability, its application in the practical experience of the project is also more abundant.

The Singapore government conducts extensive industry testing and trial of e-plan check to ensure the operation of the system and to keep $\mathrm{it}^{[4]}$. The Singapore Construction Authority (BCA) also focuses on communication with the industry and brings together major IT vendors through more than two seminars each year to share information on IFC-based BIM tools ${ }^{[5]}$. From these practices can be seen, government departments to assume the administrative approval of the link, as soon as possible with the introduction of building information model-related technologies and standards to drive the development of technology and related industries, so as to promote the development and application of building information model. The government fully combines the owners and the role 
of administration to promote the technological innovation and engineering innovation, and play a role in the whole society.

Japan first put forward the concept of information, and in 1995 began to vigorously promote the construction industry information ${ }^{[6]}$.The JIA BIM Guide, published by the Japan Institute of Architecture (JIA), has several features:First, clear the design firm BIM staff configuration;Second, the relevant rules of model data transfer are put forward.Thirdly, a new model of engineering construction based on BIM is proposed.Fourth, the BIM investment costs and other social and environmental issues ${ }^{[7]}$. Since most of Japan is a fixed-price contract, its biggest beneficiary is different from that of the United States, and therefore, when the standard is developed, it refers to the United States and combines the characteristics of their own country.

Table 1 Comparison of BIM Development Policies in Different Countries

\begin{tabular}{|c|c|}
\hline country & policies \\
\hline $\begin{array}{l}\text { United } \\
\text { States }^{[8,9]}\end{array}$ & $\begin{array}{l}1 \text { In 2003, GSA launched the National 3D-4D-BIM program. } \\
2 \text { In March 2005, USACE set up a project delivery team to study the value of } \\
\text { BIM and advise on BIM application strategies. } \\
3 \text { In October 2006, USACE released a 15-year BIM development route plan. } \\
4 \text { Respectively,with 2007,2012, 2015, BIM Standards Development Committee } \\
\text { NBIMS First Edition, Second Edition and Third Edition. }\end{array}$ \\
\hline $\begin{array}{l}\text { United } \\
\text { Kingdom }^{[1} \\
0,11,12,13]\end{array}$ & $\begin{array}{l}1 \text { In May 2011,the British Cabinet Office issued the "Government Construction } \\
\text { Strategy2011-2015", to develop a clear stage goal. } \\
2 \text { In March 2016, the Cabinet Office of the Government continued to issue a } \\
\text { new version of "Government construction strategy2016-2020". } \\
3 \text { Standard setting: BS1192:2007 "building engineering information } \\
\text { collaborative work norms",PAS1192-2:2013"project construction delivery } \\
\text { BIM information management procedures",PAS1192-3:2014"Project } \\
\text { operation BIM information management procedures",BS1192-4:2014 } \\
\text { "COBIE format information coordination work specification to meet the } \\
\text { requirements of the owner's information interaction",PAS1192-5:2015 "BIM } \\
\text { digital environment and intelligent management safety regulations". }\end{array}$ \\
\hline $\begin{array}{l}\text { Singapore } \\
{[5,14,15]}\end{array}$ & $\begin{array}{l}1 \text { The government has developed a BIM implementation plan: from } 1997 \text {, it has } \\
\text { proposed the establishment of an information system to } 2016 \text { through all the } \\
\text { professional use of BIM technology. } \\
22008 \text { to 2009, the Singapore government seven departments jointly adopted } \\
\text { the 3D electronic submission building BIM model. } \\
3 \text { In } 2010 \text {,the Singapore government adopted the 3D electronic submission } \\
\text { structure BIM model. } \\
4 \text { In } 2012 \text {, BCA released the "BIM Guidelines for Singapore BIM" specific } \\
\text { conditions. } \\
5 \text { Singapore BIM Fund launched and updated } 2013 \text { and } 2015 \text { in } 2012 \text {. }\end{array}$ \\
\hline $\begin{array}{l}\text { Japan } \\
{[7,16]}\end{array}$ & $\begin{array}{l}1 \text { March 2010,has chosen a government construction project as a pilot to } \\
\text { explore BIM in the design of visualization, information integration and the } \\
\text { implementation of the value of the process. } \\
2 \text { In 2012, the Japan Architecture Society (JIA) officially released the "JIA BIM } \\
\text { Guideline" BIM guidelines. }\end{array}$ \\
\hline
\end{tabular}

A Summary of BIM Policies in China.China's Ministry of Housing and Urban Construction in 2011 released the "2011-2015 construction industry information development program" also made it clear that the "second five" period, the basic realization of the construction enterprise information system popularization, accelerate the adoption of BIM in engineering ${ }^{[17]}$.The BIM Technology 
Application Advancement Schedule was clarified in the Notification of the Application of the Guidance on the Advancement of Building Information Models issued in June 2015.Pointed out that by the end of 2020, the construction industry Class A survey, design units and premium, a housing construction enterprises should master and achieve BIM and enterprise management systems and other information technology integration integration application ${ }^{[18]}$.Recently, the Ministry of Housing and Urban and Rural Development has compiled and published the Outline of the Development of Informatization of Construction Industry in 2016-2020. Proposed to accelerate the integration of information technology and construction industry in depth, including accelerating the application of BIM.

In the standard development, China began in early 2012, in the "2012 on the issuance of the construction project standard to develop a revised plan notice" proposed five BIM-related standards development work, the end of 2014 and started the construction engineering design information model mapping Standard preparation work, but the BIM standards are in the delay in the preparation of which design information mapping standards are expected to be completed in December this year $^{[19]}$.

\section{Conclusions}

Although China has developed a series of relevant policies and guidance, but BIM in many cases has become a display tool, many companies invest so much resources, but the actual effect is unsatisfactory.There are many reasons for this, government policy is one of them.

Through the above comparative analysis, combined with China's actual situation, I summed up a few suggestions:

First, enhancing external motivation. On the current domestic situation, China will BIM technology directly into commercial benefits there is a distance, and "benefit" is one of the BIM application driver.It is recommended that the government adopt a small-scale public project as a pilot project and use a certain incentive policy to work with high-end owners to gradually expand the application of BIM through the BIM application of the pilot project, allowing the owner to see the benefits and the complete BIM application model.

Second, exploring the standard contract text. It is recommended that the standard contract text for the project be developed with the authority of the China Academy of Building Research and other legal representatives of the project participants before the pilot project.And in the pilot project to try, at the same time the establishment of the feedback mechanism of the staff, timely amendments and improve the contract text.

Third, the financial incentives and technical guidance.It is recommended that the government invite university researchers to conduct research on BIM pilot projects and encourage research results to be published in industry magazines such as financial support for enterprise BIM applications or a strong BIM research team to conduct technical guidance.

Fourth, the establishment of fund cultivating talent.In view of the current shortage of BIM talent, it is recommended that the government set up a special fund in colleges and universities dedicated to BIM-related software research and development, for the community transport BIM technical personnel.

Fifth, standards and pilot projects at the same time.In the BIM project pilot project, the joint industry associations and university researchers to prepare the BIM standard and jointly prepared the standard trial in the project, through practice to find the problem, timely correction.

\section{References}

[1] Hong Pang. BIM development in China's architectural design status [J]. Architecture and culture, 2015.In Chinese 
[2] Wong AKD,Wong FKW,Nadeem A.Comparative roles of major stakeholders for the implementation of BIM Conference on Changing Roles:New Roles,New Challenges, Noordwijk Aan Zee,The Netherlands,5-9 October.Development Bureau,Government of the Hong Kong Special Administrative Region,2009.

[3] Leite F,Akinci B.Formalized representation for supporting automated identification of critical assets in facilities during emergencies triggered by failures in building systems[J].Journal of Computing in Civil Engineering,2012,26(4):519-529.

[4] Yong Zhang, Jun Fu.Study on China's BIM Development Strategy from the Experience of New and America [J]. Value Engineering, 2013.In Chinese

[5] Singapore BIM Technology Application Report.Dong Ouyang[J].In Chinese

[6] On the launch of the BIM introduction project in the government building maintenance business,http://www.mlit.go.jp.

[7] Japan Architecture Society. BIM Guidelines,JIA.2014:9.

[8] General Services Administration.General Services Administration(GAS)3D-4D BIM Program.http: //www.gsa.gov/portal/category/21062.

[9] US Army Corps.U.S.Army Corp of Engineers(USACE), "Building Information Modeling( BIM)-A Road map for Implementation to Support MILCON Transformation and Civil Works Projects within USACE".

[10] BS1192-4:2014.

[11] B/555 Road Map.

[12] Ling Ye.Overview of BIM Development in UK Construction Industry[J].2016.In Chinese

[13] Embedding Building Information Modelling (BIM) within the taught curriculum.

[14] Yong Zhang,Jun Fu. On China 's BIM Development Strategy from the Experience Of Singapore and the United States[J]. Value Engineering, 2013.In Chinese

[15] Teo Ai Lin Evelyn, Cheng Tai Fatt. Building Smart -A Strategy for Implementing BIM Solution in Singapore [EB/OL] . http://www.itsc.org.sg/pdf/5_BIM.pdf. 2011,8.

[16] J-BIM,http://j-bim.gloobe.jp

[17] Ministry of Housing and Urban-Rural Development of the People's Republic of China. 2011-2015construction industry information development program,2011. In Chinese

[18] Ministry of Housing and Urban-Rural Development of the People's Republic of China.On the application of information to promote the construction of information model,2015.In Chinese

[19] China University BIM Master Education Individual thinking,Guanpei He blog.In Chinese 